\title{
Impacts of Migration on Poverty Reduction: A Critical Analysis
}

Laxman Singh Kunwar (PhD)*

\begin{abstract}
This paper attempts to describe impacts of migration on poverty reduction at individual, households, community and national level. Both internal and international migration phenomenon including working environment of migrants are analyzed. The paper is based on secondary sources of information with aim of find evidence on linkages between migration and poverty at individual, household and community and National levels. Migration phenomenon has shown the evidences of in reducing poverty level but migrants are being compelled to work in an exploitative and unhygienic environment. Female migrants are being more victims of exploitation than male migrants. The poverty reduction has been gained in return of exploitative and health hazards working environment of migrants can be considered as an injustice to migrants and their place of origin as well as countries of origin.
\end{abstract}

Key words: Poverty, remittance, migrants, economy \& development.

\section{Introduction}

Migration has become an integral part of the current global economy. Both internal and international migration can have major development and poverty implications for individuals and their families, communities and national economics of origin and destination. Poor people migrate internally, but also internationally. Human Development Report estimated that the number of internal migrants is about four times the total number of international migrants (UNDP, 2009). In 2010, 214 million people were living outside their countries of birth and estimated remmitted amount of US\$440 billion worldwide by international migrants (World Bank, 2011). The number of people who move within

\footnotetext{
${ }^{*}$ Dr. Kunwar is an Associate Professor of Department of Population Studies at Patan Multiple Campus and Faculty Associate of Central Department of Population Studies, Tribhuvan University.Email:kunwarlsk@gmail.com
} 
natinal borders is much higher than international migrants. Both internal and international migrations can have major development implications for origin and destination areas (IOM, 2020).

The current global estimate is that there were around 281 million international migrants in the world in 2020, which equates to 3.6 percent of the global population. Overall, the estimated number of international migrants has increased over the past five decades. The total estimated 281 million people living in a country other than their countries of birth in 2020 which was 128 million more than in 1990, and over three times the estimated number in 1970. Despite COVID-19, remittance flows remained resilient in 2020, registering a smaller decline than previously projected. Officially recorded remittance flows to low and middle-income countries reached $\$ 540$ billion in 2020, just 1.6 percent below the 2019 total of $\$ 548$ billion (WB, 2020).

The number of people who move within national borders is much higher than international migrants. It has been estimated that the number of internal migrants is nearly four times the number of international migrants (UNDP 2009). Both internal and international migrations can have major development implications for origin and destination areas (IOM, 2020).

Poverty In 1995, the World Summit on Social Development in Copenhagen defined poverty as a condition characterized by severe deprivation of basic human needs, including food, safe drinking water, sanitation facilities, health, shelter, education and information (United Nations, 1995). Poverty is not only defined by earnings but also by access to services, including: a lack of income and productive resources to ensure sustainable livelihoods; hunger and malnutrition; ill health; limited or lack of access to education and other basic services; increased morbidity and mortality from illness; homelessness and inadequate housing; unsafe environments and social discrimination and exclusion (UN, 1995). Robert Chambers (1983) referred to the idea of poverty as a multidimensional concept, reflecting clusters of disadvantage. Blanco (2002) defined poverty 'as the total absence of opportunities, accompanied by high levels of undernourishment, hunger, illiteracy, lack of education, physical and mental ailments, emotional and social instability, unhappiness, sorrow and hopelessness for the future'. Poverty is also characterized by a chronic shortage of economic, social and political participation, relegating individuals to exclusion as social beings, preventing access to the benefits of economic and social development and thereby limiting their cultural development (Blanco, 2002). All these definitions define poverty from a broad perspective, providing certain criteria such as state of employment and income, food security, type of shelter, access to education, health and sanitation, and level of social and economic inclusion. 
International migration can have a positive impact on poverty reduction through the generation of migrant remittances. Adams and Page (2003) however show that a 10 percent rise in the number of international migrants results in a 1.6 percent decline in the poverty headcount at national level (Adams \& Page, 2005). Remittance and migration driven economy has reduced poverty in Nepal from 42 percent in 1996 to 25.16 percent in 2012 (CBS, 2011). Reduction of poverty has helped in diversification in livelihoods, greater ownership and acquirement of assets and capital.

\section{Objectives}

The aim of this paper is to review existing literature, and find evidence on linkages between migration and poverty at individual, household, community and national levels. Recently, evidence has emerged on the linkages between migration and development at both global and national levels.

\section{Methodology}

This paper reviews the existing literature on migration and remittances and its critical role in reducing poverty at individual, household, community and national levels. The literature develop by IOM, World Bank and UN agencies including various scholars are used to accomplish this paper.

\section{Findings and Discussions}

As mentioned earlier in this section the poverty analysis are made at individual (migrants themselves), household, community and national levels. In addition, the discussion will incorporate the existing working situation of migrants including their exploitative and hazardous situation in place of destination.

\section{Implications of Migration for Individual Migrants}

This section looks into the impact of migration on the migrants themselves. It explores the migration alternatives available to poor men and women and the level of economic and social wellbeing attained by them.

The cost of migration is a major hindrance for poor people who want to move. Migrating shorter distances incurs lower costs, an observation which has led some to argue that poor people tend to engage more in short distance (internal) migration, such as rural to rural or rural to urban migration (Abrar \& Seeley, 2009). In some cases distances from rural areas 
to domestic urban migration centers may be greater than those to cross-border or regional migration destinations. People who reside in border areas may prefer to cross international borders rather than migrate internally (WB, 2011). One of the reasons why the migrants are drawn to certain destinations in particular is the available social capital and support networks there. In addition to social capital, cost and distance, well-established colonial links may play a role (Samaddar, 2003). In most migration corridors, during the initial migration phase, international migration tends to be accessed more by those from relatively better off backgrounds. Compared to the non-poor, members of poorer communities often resort to risky and generally irregular ventures, in order to migrate internationally. Female domestic workers in Gulf countries who migrate from South and Southeast Asia are often from poorer backgrounds (Raharto, 2011). There is growing demand for domestic workers in the Gulf and Southeast Asia because an increasing number of women are taking up formal employment and assistance is required for household maintenance. An aging population in some of the destination countries in the Gulf has also caused a need for caregivers. These two scenarios have created migration opportunities for women from poorer communities (Shah, 2008).

Majority of migrants, be they internal, cross-border, regional or contract workers, can benefit economically from their moves in two ways. Firstly, migration increases livelihood and employment opportunities, and secondly, it often increases their financial income (Afsar, 2009). The Nepal Institute of Development Studies (NIDS) and the World Bank (2009) showed that the monthly income of Nepalese migrants in Middle Eastern countries was 7.4 times higher than the average monthly income in Nepal. Internal migrants also earned 7.61 per cent more than those who do not migrate within Nepal (Adhikari, 2011). Although it was found that there are more internal migrants than international migrants, it seems that short-term contractual international migration has more potential to help people move out of poverty. The literature on gender and migration indicates that autonomous female migrants often originate from poor economic and socially powerless positions. However, few studies compare the impacts of such migration on poverty levels of migrant women, and their families' potential to climb out of poverty, with non-migrant families from similar socioeconomic backgrounds (IOM, 2000).

Adhikari (2011) showed how Nepalese workers in Qatar experienced differences in work conditions and health coverage on the basis of their average income of unskilled short-term international migrants ranges between US\$150 and US\$2,000. Unskilled cross-border migrants' monthly income ranges from US\$22 to US\$60. Research done by the Economic and Social Commission for Asia and the Pacific (ESCAP, 2008) shows how Indonesian migrants in Malaysia are more exposed to health risks with more reported incidents of 
illness and injuries than local workers in the same occupation. Srivastava (2005) notes that in India most poor internal migrants live in urban slums under unhygienic conditions. These living conditions lead to health problems and various diseases.

Some of the problems mentioned above are linked to work entitlements whilst some can be linked to faulty urban planning. Living space for migrant and non-migrant service providers has not been allocated in urban planning. Ratha and Mohapatra (2011) highlight that most internal and international migrants move to the urban centers of developing countries because of employment opportunities there, with many working in the informal segments of the business, transport, crafts and services sectors.

Existing studies show that migrants are often vulnerable to health risks at their destination, where they may lack access to proper care. For example, female labour migration to the Free Trade Zone (FTZ) in Sri Lanka has increased migrants' risk of sexually transmitted diseases and caused a rise in unwanted pregnancies (Hettiarachchi, 2001). Vulnerability to HIV/AIDS has been identified as a major concern for certain types of mobile populations. The prevalence of HIV among migrants and their partners is significantly higher compared to non-migrants in South Africa (Lurie, 2006) On the one hand, migration can reduce poverty amongst migrants through access to better income and employment opportunities, whilst, on the other hand, it also increases their risk of ill health and deadly diseases, perhaps keeping them in, or forcing them back into, poverty. Thus, migration can have different, at times contradictory, impacts. Freemantle (2011), in the South African context, and Dang (2005), in the context of north Vietnam, highlight incidences of return migrants passing the HIV/AIDS virus on to their spouses in their countries of origin. Lurie et al. (2003) found that among South African migrants, in situations where the male partner was abroad and the female partner remained at home, about a third of the females were infected.

Female migrants, including domestic workers, are often vulnerable to mistreatment and abuse. As discussed previously, international migration for domestic work is widespread in Asia (Lian, 2009) and is one of the most common occupations amongst internal migrants in South Africa (Freemantle, 2011). Internal and international domestic migrant workers work within the private sphere of the home of the employer. As such, they are typically excluded from prevailing labour laws in destination areas (Khan \& Harroff Tavel, 2011). In the case of short-term contract international migration, the passports of domestic workers are often confiscated and their movements are restricted beyond the household, particularly in the Gulf countries. Movement of homebound internal domestic workers is also restricted. Some are subjected to physical and sexual violence affecting 
their physical and mental wellbeing (Scaria, 2004). A study of North-South migrants in Ghana indicated that some of the migrants returned home with illnesses. Some were also found to have engaged in commercial sex activities and others had been forced to have sex, and thus were exposed to sexually transmitted infections (Anarfi, 2001). The patriarchal social structures in the various origin countries are no less restrictive than those in the destination areas, the concept of the home in the rural setting usually involves inner courtyards and connected households, where women have more freedom of movement and more contact with friends and relatives. In destination countries, domestic workers are confined to urban high rise flats or, even worse, the kitchen areas of private houses, which restricts their movement and isolates them. The physical and mental wellbeing of homebound domestic workers are further affected by physical and sexual violence. Some domestic workers, unable to cope with these conditions, flee from their employers. In some cases, they fall prey to traffickers (Ruhunage et al., 2011). There are examples in the cases of Sri Lanka, Bangladesh and Nepal, where female migrants are lured into the sex trade by fellow countrymen, often with the promise of better job opportunities. In order to save themselves from abusive employers, some of these women ended up murdering their employers or committing suicide (Raharto, 2011). Both male and female migration to the Gulf is managed under the Kafala system. Kafil means sponsor and under this system migrants are tied with a Kafil. Technically, the Kafil pays for the migrant to come and provide services to the Kafil. Therefore, a worker cannot change the Kafil or take some other job without the consent of the Kafil (Khan \& Harroff-Tavel, 2011).

These discussions highlight that poor people migrate both internally and internationally. Compared to their situation before they migrated, the income of migrants often increases and poverty reduces significantly. It is important to note, however, that this is not the case for all migrants some find themselves in serious debt, which they are unable to repay and causes them to fall into further difficulties. The risks that migrants face are not only financial. Internal and international semi and low skilled migrants may also face poor living and health standards whilst abroad, and homebound domestic workers are situated in the most unprotected positions.

\section{Implication of Migration at Households Levels}

Migration increases household income and acts as insurance during unforeseen events. A range of literature is available on the economic impact of migration on migrant households and extended families, in both Asia and Africa. There is a general consensus that migrant remittances constitute a valuable input to family income. Some country specific evidence shows that migration reduces poverty at the family level. Although it appears obvious that 
migration leads to an increase in family incomes, particularly those of internal and shortterm contract international migrants, evidence linking reduction of poverty to migration at the family level is not always comparable.

Ratha et al. (2011) highlighted that international migration contributes to the formation of human capital. Various studies showed that remittances from international migration are disproportionately spent on education and health, rather than on everyday consumption (World Bank, 2006). The literature on internal migration in South Asia, however, shows that the bulk of the remittances are spent on consumption (Abril \& Rogaly 2001). Once in school, the children of international migrants are more likely to finish their education as the increased income from remittances provide additional financial resources (Ratha et al., 2011). Compared to non-migrant households, children of migrants tend to marry early (Perera \& Siddiqui, 2000).

The migration of their male spouses appears to have a positive influence on many leftbehind wives, who receive and manage the remittances. In the absence of a husband, women become the head of the household and their decision-making autonomy increases. Hoang (2011) found that, despite their immobility, the extended families of internal migrants in source areas have played a significant role in migration. Migrants often receive various kinds of support, including funds mobilized through family networks. In turn, they are expected to fulfil their duties to those family members (Hoang, 2011). Hugo (2002) suggests that in Indonesia ties between the elderly and their adult migrant children have been weakened by international migration. In these instances, migration creates a vacuum for the much needed care of the elderly parents. In Bangladesh and Sri Lanka, female migration has increased the workload of elderly women whose children have migrated abroad (IOM, 2000).

In Asia and Africa, migration impact studies have mainly focused on households, income levels, human capital formation, women's empowerment, investment and the emotional strain on families. Migration of family members helped the majority of the left behind households to increase their family incomes, and reduces poverty at the family level. International migration contributes to the formation of human capital.

\section{Implication of Migration at Origin Communities of Migrants}

In South and Southeast Asia, micro-level studies have found mostly positive and a few negative relations between migration and the development of origin communities. The left-behind community comprises an important part of self-identity of migrants both 
in Asia and Africa. A general understanding exists that migrants often contribute to the welfare of their communities of origin. Studies show that first-generation diaspora members can play an important role in ensuring home community welfare through the provision of various services and donations to their educational, religious and sociocultural institutions. While the second and third-generation offspring of migrants may not maintain very close connections with members of their immediate families, studies show that they do make attempts to connect with their roots through charity and philanthropy (Sidel, 2007).

Community development activities organized by migrants may have major poverty reducing implications, as the services mentioned above attempt to target the poorest of the poor. The contribution of the diaspora, in the form of remittances, contributes to the alleviation of hardship of individuals or families in places of origin. The support given by migrants, towards food, clothing and healthcare needs, often functions as a safety net for poorer relatives or other villagers. A number of studies suggest that migrant remittances play a crucial role in rural economic development (Hugo, 2002)

\section{Implication of Migration at National Economy}

When it comes to international, short-term contract and settler migration, the impact of migration on national economies of origin countries has been well researched. Migration and remittances have both direct and indirect effects on the welfare of populations in origin countries. A cross-country study of 71 developing countries found that a 10 per cent increase in official international remittances per capita will lead to a 3.5 per cent decline in the share of people living in poverty (Adams \& Page 2005). In recent years, global remittance flows have significantly increased. Ratha (2007) identified remittances as perhaps the most tangible and least controversial link between migration and development. The true size of remittances, including unrecorded flows through formal and informal channels, is likely to be even larger. In Nepal, internal migrants' remittances constitute 2.8 per cent of the total GDP whilst the remittances received from international workers constitute 23.8 per cent of the total GDP (WB, 2011).

\section{Conclusion}

Migrant remittances create considerable multiplier effects in the local economies of origin areas and countries. In some cases remittances may have negative impacts on communities of origin, for example by increasing existing inequalities or creating dependency on such external flows (Yue, 2008). In the case of Nepal, remittances are mainly invested 
into urban areas and thus migrant origin areas do not receive economic benefits from remittances, other than to maintain subsistence (Adhikari, 2011). Various types of internal and international migration contributes to poverty reduction at individual, households, community and the national level, although rural to urban internal and international migrants from least developing to developing and developed are compelled to work in an exploitative and unhygienic working environment. Therefore, poverty reduction through remittances at origin of migrants has been well accepted global phenomenon but migrants being compelled to work in exploitative and unhygienic working environment at destination is questionable to all stakeholders of migrants.

\section{References}

Abrar, C. R., \& Seeley, J. (2009). Social protection and livelihoods: Marginalized migrant workers of India and Bangladesh. Dhaka: University Press Limited, Bangladesh.

Abril, E. R., \& Rogaly, B. (2001). Migration and social relations: An annotated bibliography on temporary migration for rural manual work. CLARA: Working papers on Asian labor. amsterdam. International Research Programme on Changing Labor Relations in Asia.

Adams, R. H., \& Page, J. (2005). Do international migration and remittances reduce poverty in developing countries? World Development, 33(10), 1645-1669.

Adams, R. H., \& Page, J. (2008). Remittances, consumption and investment in Ghana. World bank policy research working paper, No. 4515. Washington DC: World Bank.

Adhikari, J. (2011). Impact of internal and international migration in Nepal. Unpublished paper prepared for the research programme consortium on migrating out of poverty. Brighton: University of Sussex.

Afsar, R. (2009). Unravelling the vicious cycle of recruitment: Labor migration from Bangladesh to the Gulf States. Geneva: ILO.

Anarfi, J. K. (2001). Migration and livelihoods in the era of AIDS: A west African focus with emphasis on Ghana. https://www.researchgate.net/publication/265072555

Blanco, R. O. (2002). How we define poverty? UN Chronicle, 39(4).

Central Bureau of Statistics (CBS). (2011). Nepal living standard survey, 2010/11. Kathmandu: Central Bureau of Statistics, Nepal.

Chambers, R. (1983). Rural development: Putting the last first. Upper Saddle River, New 
Jersey: Prentice Hall. https://www.populationasia.org/CHAMPSEA/CHAMPSEA \%20Laguna. pdf.

Dang, N. A. (2005). The HIV/AIDS vulnerability of labor out-migrants and its consequences on the left-behind at the household level. Annual meeting of Southeast Asian studies. Natou County, Taiwan, Graduate Institute of Southeast Asian Studies of the National Chi Nan University.

Economic and Social Commission for Asia and the Pacific (ESCAP). (2008). Looking into Pandora's box: The social implications of international migration in Asia. Asia-Pacific Population and Social Studies Series, 164. New York.

Freemantle, I. (2011). Impact of internal and international labor migration: South Africa. Unpublished paper prepared for the research programme consortium on migrating out of poverty. Brighton: University of Sussex.

Hettiarachchi, T. (2001). The risk of pregnancy and the consequences among young unmarried women working in a free trade zone in Sri Lanka. Asia Pacific Population Journal, 16(2), 125-140.

Hoang, L. (2011). Impact of internal and international labor migration: South-East Asia. Unpublished paper prepared for the research programme consortium on migrating out of poverty. Brighton: University of Sussex.

Hugo, G. (2002). Effects of international migration on the family in Indonesia. Asian and Pacific Migration Journal, 11(1), 13-46.

Hugo, G. (2003). Migration and development: A perspective from Asia. International Organization for Migration Research Series No. 14, Geneva: International Organization for Migration.

International Organization for Migration (IOM). (2000). Temporary labor migration of women: Case studies of Bangladesh and Sri Lanka. Co-authored by Siddiqui, T. and Perera, M. Dominican Republic: INSTRAW.

International Organization for Migration (IOM). (2020). World Migration Report. Geneva: IOM.

Khan, A., \& Harroff Tavel, H. (2011). The implications of the sponsorship system: Challenges and opportunities. Paper presented at the international conference on strengthening dialogue to make migration work for development in the ESCAP and ESCWA regions, 28-30 June 2011. Beirut, Lebanon.

Lurie, M. N. (2006). The epidemiology of migration and HIV/AIDS in South Africa. 
Journal of Ethnic and Migration Studies, 32(4) 649-666.

Lurie, M. N., Williams, B., Khangelani Z., Mkayamwamburi, D., Garnett, G. P., Sturm, A.W., Sweat, M. D., Gittlesohn, J., \& Karim, S.S. A. (2003). The impact of migration on HIV-1 transmission in South Africa: A study of migrant and nonmigrant men and their partner. Sexually Transmitted Diseases, 30(2), 149-156.

Nepal Institute of Development Studies (NIDS). (2009). Nepal Migration Survey. Kathmandu: NIDS (unpublished).

Perera, M., \& Siddiqui, T. (2000). Temporary labor migration of women: Case studies of Bangladesh and Sri Lanka. United Nations international research and training institute for the advancement of women and international organization for migration. Santo Domingo, Dominican Republic

Raharto, A. (2011). The migratory experience of returned migrant domestic workers: The example of Indonesia. Paper presented at the international conference on strengthening dialogue to make migration work for development in the ESCAP and ESCWA regions, 28-30 June 2011, Beirut, Lebanon.

Ratha, D. \& Mohapatra, S. (2011). Remittance markets in Africa. Washington D. C.: World Bank

Ratha, D. (2007). Leveraging remittances for development. MPI policy brief, June 2007. Washington D C: Migration Policy Institute

Ratha, D., Mohapatra, S., \& Scheja, E. (2011) Impact of Migration on Economic and Social Development: A Review of Evidence and Emerging Issues. World Bank Policy Research Working Paper. Washington DC: World Bank.

Ruhunage. L. K., Lakshman, R. \& Sangasumana, P. (2011). Impact of internal and international migration in Sri Lanka. Unpublished paper prepared for the research programme consortium on migrating out of poverty. Brighton: University of Sussex.

Samaddar, R. (2003). Refugees and the State-practices of asylum and care in India, 1947-2000. New Delhi: Sage Publications.

Scaria, M. (2004) Maid in Hell. Delhi: Media House. Shah, M. N. (2008). Recent labor immigration policies in the Oil -Rich Gulf: How effective are they likely to be? ILO Asian regional paper on the governance of labor migration, working paper no. 3 .

Shah, M. N. (2008). Recent labor immigration policies in the Oil -Rich Gulf: How effective are they likely to be? ILO Asian regional paper on the governance of 
labor migration. Working paper no. 3.

Sidel, M. (2007). Vietnamese-American diaspora philanthropy to Vietnam. Boston, MA. The Philanthropic Initiative, Inc., and the Global Equity Initiative.

Srivastava, R. (2005). India: internal migration and its links with poverty and development in migration, development and poverty reduction in Asia. Geneva.

United Nations (UN). (1995). The Copenhagen declaration and programme of action: World summit for social development, 6-12 March 1995. New York: United Nations Department of Publications.

United Nations Development Program (UNDP). (2009). Human development report 2009. Overcoming barriers: Human mobility and development. New York.

World Bank (WB). (2011). Cross border labor mobility, remittances and economic development in South Asia. Prepared by RMMRU and TARU. Washington DC: World Bank.

World Bank (WB). (2020). Defying predictions, remittance flows remain strong during COVID-19 crisis. Washington DC: World Bank.

Yue, C. S. (2008). Demographic change and international labor mobility in Southeast Asia: Issues, policies and implications for cooperation in Hugo, G. and Young, S. (eds) labor mobility in the Asia-pacific region: Dynamics, Issues and a New APEC Agenda: A Survey and Analyses of Governance Challenges on Labour Migration for APEC Economies. Singapore: Institute of Southeast Asian Studies. 